\title{
A preliminary study on the affinities of Philippine, Bornean and New Guinean hepatics
}

\author{
Benito C. Tan and John J. Engel \\ c/o ALCON, 629 T. Alonzo St., Sta. Cruz, Manila, The Philippines \\ Botany Department, Field Museum of Natural History, Roosevelt Road at Lakeshore Drive, \\ Chicago, Illinois 60605
}

\begin{abstract}
The generic and specific affinities of the Philippine, Bornean and New Guinean hepatic floras were analyzed by calculating the Kroeber's percentage of similarity on the basis of recently published checklists. It is observed that the overall affinities parallel that exhibited by local moss floras except for one important difference. For the three areas, the number and distribution of species of large, actively evolving hepatic genera are noted to be disparate and with few shared taxa. Contrastingly, the large and actively evolving moss genera produce consistently large number of species in all three areas with an equally large number of shared taxa. The strong dependence of many hepatic taxa on asexual reproduction and the poor spore dispersability are accepted as the best explanation to this phenomenon.
\end{abstract}

Mosses and hepatics have fundamentally similar life histories, life forms (Mägdefrau, 1982), and life strategies (During, 1977). They also share basic ecological preferences (Pócs, 1982; Richards, 1984). Yet, their overall phytogeographic distribution patterns can be different in some regions. This was observed earlier by Buck and Thiers (1989) who reported that the mosses of the tepuis of the Guayana Highland are disappointingly low in diversity (except for Sphagnum), and yet the hepatic flora of that area is distinctive and relatively rich in taxa considered primitive. A similar incongruity is reported below for the distribution patterns of mosses versus hepatics within Malaysia, a vast region embracing the Philippines, Borneo and New Guinea (Fig. 1).

The Philippine moss flora, analyzed for its phytogeographical affinity (Tan, 1984), is relatively closer to the Bornean flora than to the New Guinean flora both at the generic and species levels. The same author stated that because of its geographical location and geological history, the Philippines has received several continental Asiatic elements as well as a number of Australasian taxa which do not reach New Guinea or Borneo. Admittedly, these are minority elements in the Philippine flora which, on the whole, share a great majority of taxa with Borneo, and to a lesser extent, with New Guinea.

The checklists published recently for the hepatic floras of Western Melanesia (Grolle and Piippo, 1984a), the Philippines (Tan and Engel, 1986), and Borneo (Menzel, 1988) permita similarpreliminary analysis of the phytogeographical 


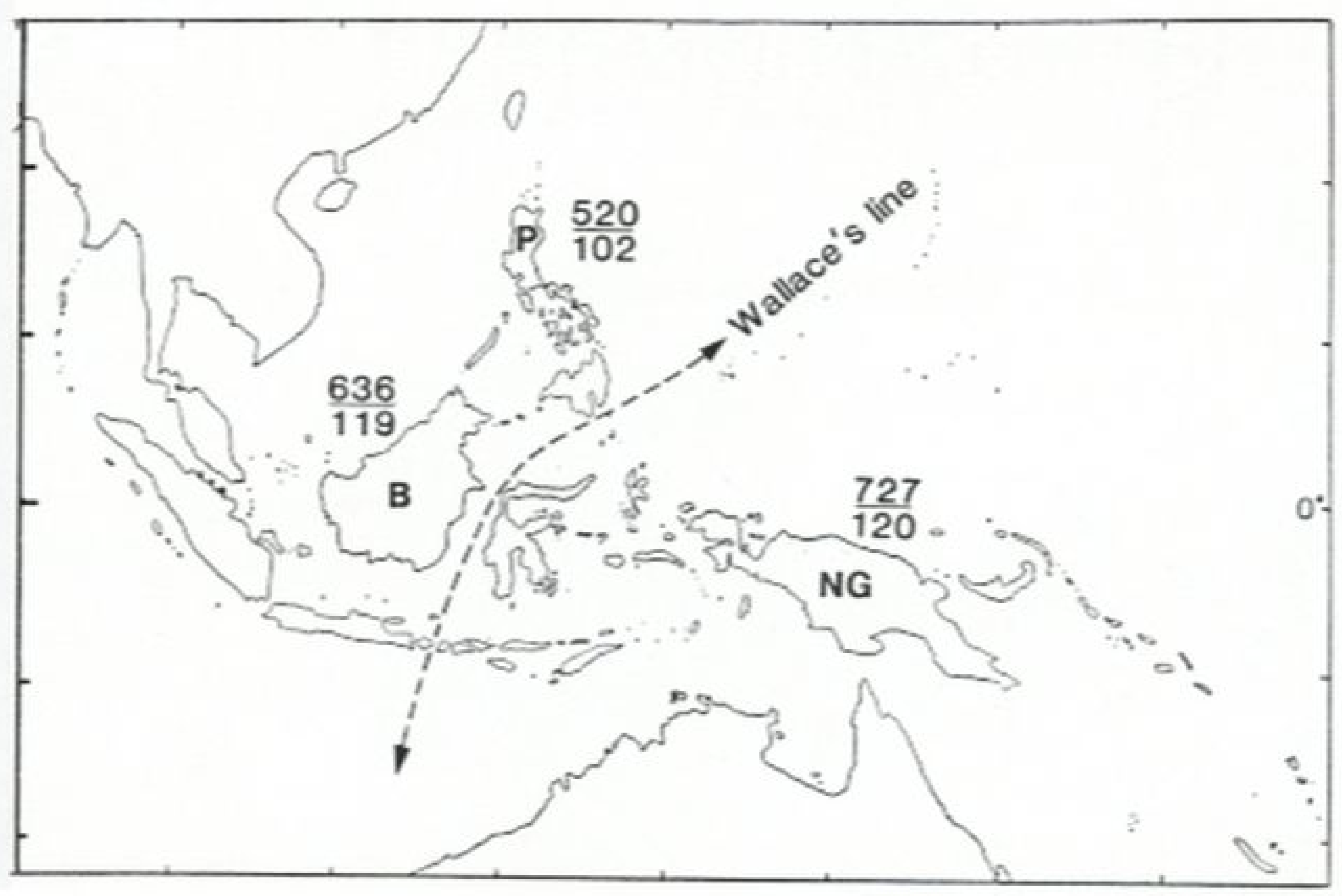

Fig. 1. Number of genara (the denominator) and species (the numerator) in Philippine (= P), Bornean (= B) and New Guinean(= NG) hepatic floras.

with the more recent publications of Gradstein and Vána (1987), Püppo (1985a-c, 1988a-b, 1989), Inoue (1989), Hattori and Piippo (1986) and Grolle and Piippo (1984b, 1986).

Table 1 shows the affinities of the Philippine, Bornean and New Guinean hepatic floras expressed in Kroeber,s percentage of generic and specific similarity. Although at the species level the Philippine-Bornean floras have a much higher percentage of affinity than the Philippine-New Guinean floras, the percentage of generic similarity is not decisively in favor of a closer Philippine-Bornean floristic relationship.

A detailed comparison was made to analyze the patterns of distribution of genera and species among these three areas. The results are presented in Tables 2-3, and highlights are discussed below.

Like its moss counterpart, the Philippine hepatic flora shows principally a Laurasian origin. It has many taxa that: (1) belong to widespread, nontropical, northern hemisphere groups (e.g., Jungermannia hyalina Lyell, Lepidozia reptans [L.] Dum., Tritomaria exsecta [Schard.]Loeske, and Marsupella emarginata [Ehrh.] Dum.); (2) have primarily a Himalayan-East Asiatic range (e.g., Kurzia makinoana [Steph.] Grolle, Trichocolea tonkinensis Steph., Bazzania sikkimensis [Steph.] Herz., Metacalypogeia cordifolia [Steph.] Inoue, and Plagiochasma spp.); and (3) belong to hyper-oceanic, North Pacific coastal groups (e.g., Makinoa crispata [Steph.] Miyake, Isotachis japonica Steph., and Bazzania japoni$c a$ [Sande Lac.] Lindb. Often these taxa fail to colonize New Guinea and/or Borneo, which lie farther to the south. Indeed, very few, like Makinoa crispata, reach New Guinea.

Borneo, on the other hand, has an insignificant number of tropical, lowland, Laurasian taxa which range widely from Sri Lanka, Indochina, Malaya, Sumatra, Java and Borneo, but do not reach the Philippines. Good examples are 
Table 1. Generic and species affinities of the Philippine, Bornean and New Guinean hepatic floras (see text for information sources).

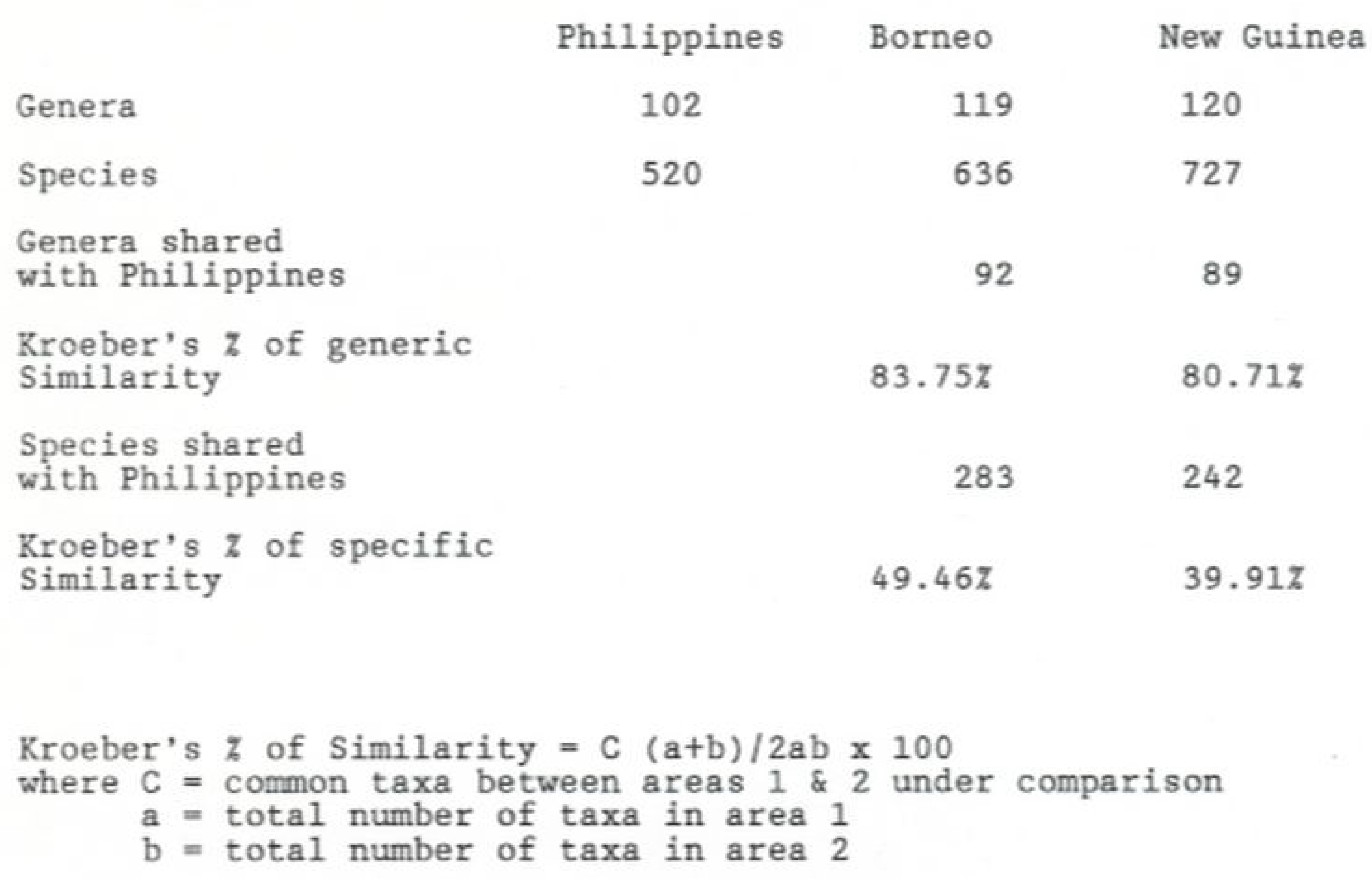

Table 2. Hepatic genera with restricted range within the three areas.

$\begin{array}{lll}\text { Philippines Only } & \text { Borneo Only } & \text { New Guinea Only } \\ \text { Metacalypogeia } & \text { Adelanthus } & \text { Anthelia } \\ \text { Notothylas } & \text { Aphanotropis } & \text { Apotreubia } \\ \text { Plagiochasma } & \text { Eopleurozia } & \text { Calatholejeunea } \\ & \text { Stenorrhipis } & \text { Cylindrocolea } \\ & \text { *Steerea } & \text { Hygrolembidium } \\ & \text { Rectolejeunea } & \text { Marsupidium } \\ & \text { Takakia } & \text { Siphonolejeunea } \\ & & \text { Pseudocephalozia } \\ & & \text { Wiesnerella } \\ & & \text { Zoopsidella } \\ \text { * endemic taxon } & & \end{array}$


Table 3. Number of species of selected hepatic genera of Philippines, Borneo and New Guinea (see text for information sources).

\begin{tabular}{|c|c|c|c|c|}
\hline Genus & $\begin{array}{l}\text { Philippine } \\
\text { Species }\end{array}$ & $\begin{array}{l}\text { Bornean } \\
\text { Species }\end{array}$ & $\begin{array}{l}\text { New Guinean } \\
\text { Species }\end{array}$ & $\begin{array}{l}\text { Common } \\
\text { Species }\end{array}$ \\
\hline Acromastigium & 4 & 16 & $10(9) *$ & 3 \\
\hline Anastrophyllum & 2 & 11 & $9(10)$ & 2 \\
\hline Bazzania & 32 & 44 & 53 & 11 \\
\hline Cheilolejeunea & 12 & 21 & 14 & 6 \\
\hline Cololejeunea & 48 & 48 & 24 & 8 \\
\hline Colura & 6 & 18 & 15 & 4 \\
\hline Drepanole jeunea & 14 & 19 & 16 & 6 \\
\hline Frullania & 40 & 44 & 82 & 16 \\
\hline Herbertus & 15 & 1 & 5 & 1 \\
\hline Lepidozia & 18 & 22 & 20 & 6 \\
\hline Marchantia & 13 & 4 & 10 & 2 \\
\hline Marsupe11a & 2 & 5 & 4 & 1 \\
\hline Metzgeria & 21 & 8 & $16(14)$ & 2 \\
\hline Plagiochila & 40 & 41 & $65(50)$ & 11 \\
\hline Porella & 6 & 1 & 4 & 1 \\
\hline Radula & 19 & 32 & $34(42)$ & 14 \\
\hline Riccardia & 6 & 10 & 29 & 0 \\
\hline $\begin{array}{l}\text { Schistochila } \\
\text { (including Paras }\end{array}$ & $\stackrel{9}{9}$ & 9 & 18 & 5 \\
\hline Telaranea & 7 & 5 & 5 & 2 \\
\hline Trichocolea & 8 & 3 & 5 & 1 \\
\hline
\end{tabular}


[Sande Lac.] Lindb. Often these taxa fail to colonize New Guinea and/or Borneo, which lie farther to the south. Indeed, very few, like Makinoa crispata, reach New Guinea.

Borneo, on the other hand, has an insignificant number of tropical, lowland, Laurasian taxa which range widely from Sri Lanka, Indochina, Malaya, Sumatra, Java and Borneo, but do not reach the Philippines. Good examples are Lopholejeunea ceylanica Steph. and Schiffneriolejeunea pulopenangensis (Gott.) Gradst. Some of these may reach as far as New Guinea via Sulawesi or the Lesser Sunda Island group.

Nonetheless, the proximity of the Philippine Islands to Borneo since the mid-Tertiary, and the presence of land bridges between them during Pleistocene glaciation have apparently allowed several taxa to migrate between the two places. As far as we know there have never existed continuous land routes at any geologic time for plants from Borneo or the Philippines to have used in reaching the New Guinean mountains. Good examples of elements shared by the Philippines and Borneo, but not with New Guinea, are Metzgeria borneensis Kuwah., Kurzia borneensis Mizut., Dactylophorella muricata (Gott.) Schust., Frullaniapulogensis Steph., Lejeunea eifrigii Mizut., Bazzania indica (Gott. \& Lindenb.) Trev. and Apomeztgeria pubescens (Schrank) Kuwah. var. kinabaluensis Kuwah.

In comparison, fewer taxa are shared by the Philippines and New Guinea. Noteworthy examples are Triandophyllum, Treubia and Symphyogynopsis. The last genus is probably present in Borneo judging by the total range reported for it in Grolle and Piippo (1986). Species belonging to this category are of Gondwandic origin or have a narrow Australasian range. In the Philippines, they are known mostly from Mindanao Island.
A few of these may have reached the northeastern Sabah State of Borneo via the southern Philippine pathway (cf. van Steenis, 1964).

One intriguing Hepatic is Tylimanthus saccatus (Hook.) Mitt. ex Schiffn. This species, according to Piippo (1985a), ranges from Australia and New Zealand to West Irian, New Guinea. Kitagawa and Kodama (1974) reported it from Mt. Kinabalu of Borneo. Tylimanthus saccatus is currently not known from the Philippines, but its absence is likely a case of under collecting. Similarly, 'nonoccurrence' of the widespread Cyathodium in Bornean rainforests and the lack of a record for the weedy Notothylas in the New Guinean flora are probably the result of human oversight.

There are at present a handful of taxa known only from Borneo and New Guinea. Examples are members of Acrobolbus, Andrewsianthus, Metahygrobiella, Cryptochila, Pseudolepicolea, Southbya, Aneura, and Gymnomitrion. The first five genera are thought to be austral taxa that have successfully crossed Wallace's Line (Schuster, 1983; cf. Fig. 1). They may be present in the southern Philippines at upper elevations.

The last three genera, together with Anastrophyllum minutum (Schreb.) Schust. and A. assimile (Mitt.) Steph., are taxa that prefer alpine habitats well above $3000 \mathrm{~m}$ within the tropics. Outside the tropics, they are rather common in high latitude regions. The absence of Philippine records for these taxa may be real owing to the absence of alpine habitats, the highest mountain in the Philippines (Mt. Apo) reaches only $2924 \mathrm{~m}$.

Borneo and New Guinea each harbor a large cluster of narrowly restricted and endemic genera. These are listed in Table 2 . The situation is likely due to the long isolation, and older geologic age of these 
Table 4. Number of species of selected moss genera in Philippines, Borneo and New Guinea.

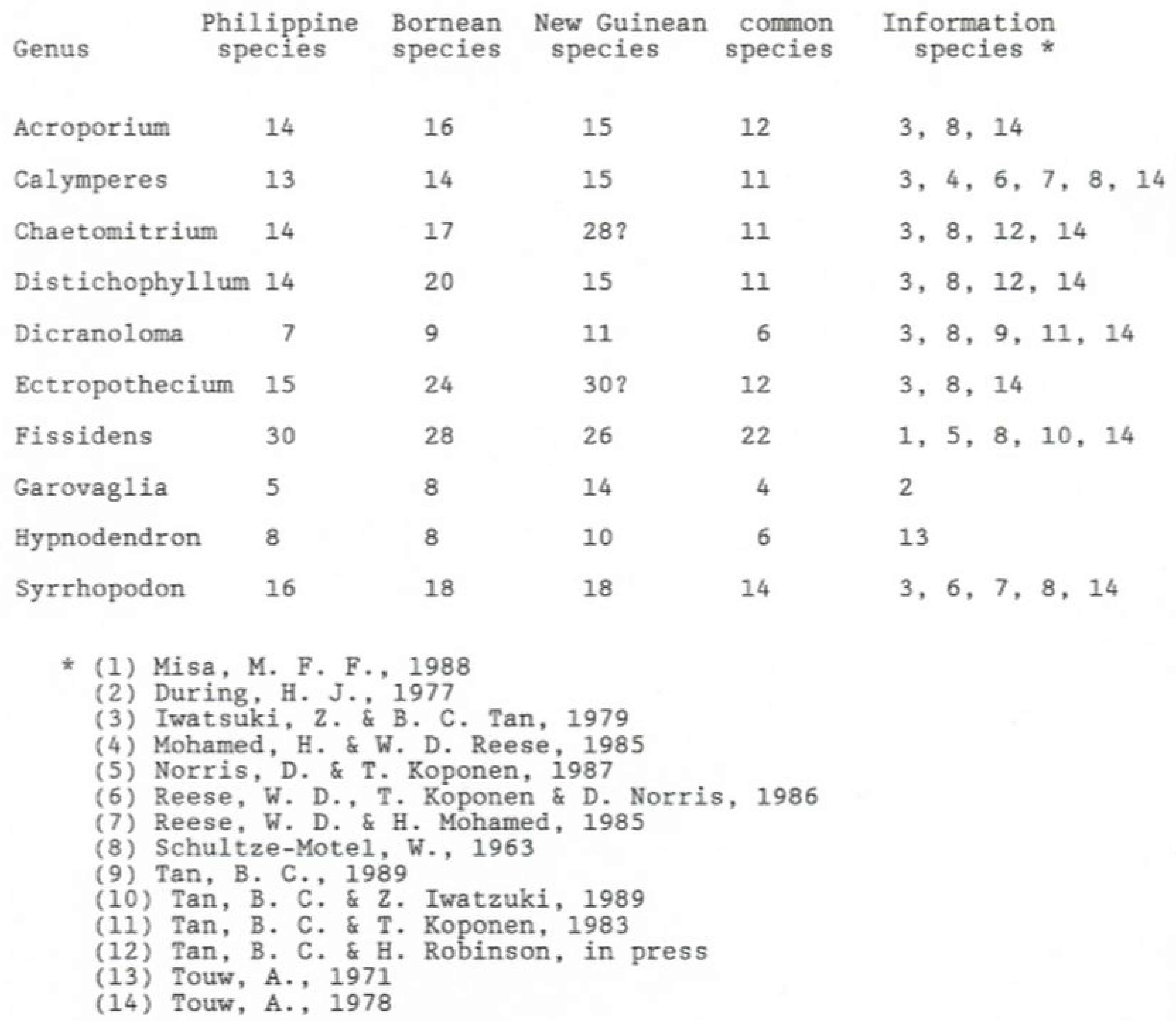


two islands.

One may state, as a general summary, that widespread Asiatic or Laurasian genera (cf. Gradstein and Vána, 1987) have more species in common between the Philippines and Borneo than between the Philippines and New Guinea. The opposite appears to be true for species belonging to genera of austral origin (cf. Schuster, 1983).

However, the parallel patterns between the distributions of Malesian mosses and hepatics described above ends here. One noteworthy feature, not seen in moss distribution patterns, emerges when one considers the number of hepatic species evolved in each of the three places and their taxonomic affinity.

Significantly, several large, 'modern' genera such as Acromastigum, Anastrophyllum, Plagiochila, Frullania, Bazzania, Colura, Herbertus, Radula, Cololejeunea, Porella, and Marchantia have conspicuously disparate numbers of species distributed in the three areas (see Table 3). Genera such as Frullania, Plagiochila and Bazzania are represented in New Guinea by a large number of species. Yet the same genera consist of a much lower number of species in the Philippines or Borneo (see Table 3). Conversely, genera like Herbertus, Cololejeunea, Metzgeria and Marchantia, which have a high species diversity in the Philippines, have speciated poorly in New Guinea and/or Borneo. More strikingly, many of these genera have a low number of species in common among the three areas (see Table 3). Thus, the differences in the species number of each area are the result of the number of endemics plus taxa shared by any two (not three) study areas. Distributional patterns for mosses are different. The species distribution within large and actively evolving moss genera in the Philippines, Borneo and New Guinea is presented in Table 4. Genera such as Acroporium, Calymperes, Chaetomitrium, Distichophyllum, Ectropothecium, Fissidens and Syrrhopodon consistently have large numbers of species in all three areas. In addition to its own endemic species, each of the three areas also shares a large assembly of common taxa.

This peculiar 'hepatic phenomenon' of having disparate distribution of species numbers and diversity across adjacent areas within the same phytogeographical unit, i.e., Malesia, is difficult to explain satisfactorily in terms of differences in local precipitation, habitat diversity and geological history. Undoubtedly, broad versus narrow species concepts provided by the authors of monographs and floras for the genera under consideration have had an effect on this hepatic phenomenon. This along could not explain the marked reduction of the number of species, in some cases nearly half the number, between neighboring area.

Under-collection on some islands may be another explanation. However, based on the numbers of past expeditions and new collections made from Malesia, all three places can be safely described as equally under collected (Touw, 1982; Prance and Campbell, 1988).

The best explanation seems to lie in the reproductive biology and spore dispersability of hepatics. Schuster (1983) has asserted that, in general, hepatics depend more than mosses on asexual diaspores for the maintainance and expansion of populations. This may have resulted in the proliferation of many clonal populations. These asexually maintained populations, often exhibiting some morphological variations interpreted as individual species, can inflate unduly the number of species in one area.

On the other hand, the relatively poor dispersability of hepatic spores may severely reduce the free flow of genes in an area and fix the species at a low number. Recently, Gradstein and Vána (1987) 
demonstrated a positive correlation between a widely disjunctive range pattern and low viability of spores in some hepatic species.

Future field studies can help to resolve this mystery by looking into the percentage of hepatic species in the Philippines, Borneo and New Guinea that employ principally asexual means of reproduction. These findings should then be correlated with the ranges of species and their individual taxonomic distinctiveness.

Acknowledgments. We are grateful to Drs. B. Thiers, S. Piipo and B. Buck for criticizing the earlier drafts of manuscript and for providing additional information. The material supports provided by the New York Botanical Garden and the Field Museum of Natural History are also acknowledged.

\section{Literature Cited}

Buck, W. R. \& B. M. Thiers. 1989. Review of bryological studies in the Tropics.Pp. 484-493. In:D. G.Campbell and H.D. Hammond (eds.). Floristic Inventories of Tropical Countries. New York Botanical Garden. New York.

During, H. J. 1977. A taxonomic revision of the Garovaglioideae (Pterobryaceae, Musci). Bryophytorum Bibliotheca 12: 1244. 1979. Life strategies of bryophytes: a preliminary review. Lindbergia 5:2-18.

Gradstein, S. R. \& J. Vana. 1987. On the occurrence of Laurasian liverworts in the Tropics. Memoirs of New York Botanical Garden 45:388-425.

Grolle, R. \& S. Piippo. 1984a. Annotated catalogue of Western Melanesian bryophytes. I. Hepaticae and Anthocerotae. Acta Botanica Fennica 125: 1-86.

$\longrightarrow$ \&_.1984b.BryophytefloraoftheHuonPeninsula,

Papua New Guinea V. - Lepidoziaceae subfam. Zoopsoideae and Cephaloziaceae subfam. Schiffnerioideae (Hepaticae). Annales BotaniciFennici21:299-307.

$\mathbf{A - 1 9 8 6}$. Bryophyteflora of the HuonPeninsula, Papua New Guinea XVI. - Pallaviciniaceae (Hepaticae). Acta BotanicaFennica 133:59-79.

Hattori, S. \& S. Piippo. 1986. Bryophyte flora of the Huon Peninsula, Papua New Guinea. XV. Frullania (Frullaniaceae, Hepaticae). Acta Botanica Fennica 133:25-58.

Inoue, H. 1989. The bryophytes of Sabah (North Borneo) with special reference to the BRYOTROP transect of Mount Kinabalu. V. Plagiochila (Plagiochilaceae, Hepaticae). Willdenowia 18: 555-567.
Iwatsuki, Z. \& B. C. Tan. 1979. Checklist of Philippine mosses. Kalikasan, Philippine Journal of Biology 8: 179-210.

Kitagawa, N. \& T. Kodama. 1974. Enumeration of Hepaticae collected by Drs. S. Kokawa and M. Hotta in Sabah (North Borneo) II. Bulletin of Osaka Museum of Natural History 28: 3348.

Mägdefrau, K. 1982. Life forms of bryophytes. Pp. 45-58. In: A. J. E. Smith (ed.) Bryophyte Ecology. Chapman and Hall, London.

Menzel, M. 1988. Annotated catalogue of the Hepaticae and Anthocerotae of Borneo. Journal of Hattori Botanical Laboratory 65: 145-206.

Mohamed, H. and W. D. Reese. 1985. Syrrhopodon (Musci: Calymperaceae) in Malaysia and adjacent regions. Bryologist 88:223-254.

Norris, D. and T. Koponen. 1987. Bryophyte flora of the Huon Peninsula, Papua New Guinea. XX. Fissidentaceae, Mitteniaceae, Phyllodrepaniaceae, Phyllogoniaceae and Sorapillaceae (Musci). Annales Botanici Fennici 24: 177-220. Piippo, S. 1985a. Bryophyte flora of the Huon Peninsula, Papua New Guinea. X. Jackiellaceae, Scapaniaceae, Arnelliaceae and Acrobolbaceae (Hepaticae). Acta Botanica Fennica 131:89-98.

1985b. Ibid. XII. Geocalycaceae (Hepaticae). Acta BotanicaFennica 131: 129-168.

.1985c.Ibid.XIII. ArachnioosisandKurzia(Lepidoziaceae subfam. Lepidozioideae, Hepaticae). Acta Botanica Fennica 131:169-179.

.1988a.Ibid. XXII. Targioniaceae, Wisnerellaceae, Aytoniaceae and Ricciaceae (Marchantiales, Hepaticae). Annales BotaniciFennici25:97-107.

.1988b.Ibid.XXIII. Treubiaceae, Allisoniaceae and Makinoaceae (Metzgeriales, Hepaticae). Annales Botanici Fennici25: 159-164.

1989. The bryophytes of Sabah (North Borneo) with special reference to the BRYOTROP transect of Mount Kinabalu. III. Geocalycaceae (Hepaticae). Willdenowia 18: 513-527.

Pócs, T. 1982. Tropical forest bryophytes. Pp. 59-104. In: A. J. E. Smith (ed.). Bryophyte Ecology. Chapman and Hall, London. Prance, G. T. and D. G. Campbell. 1988. The present state of tropical floristics. Taxon 37:519-548.

Reese, W. D., T. Koponen and D. Norris. 1986. Bryophyte flora of the Huon Peninsula, Papua New Guinea. XIX. Calymperes, Syrrhopodon and Mitthyridium (Calymperaceae, Musci). Acta Botanica Fennica 133: 151-202.

\& H. Mohamed. 1985. A synopsis of Calymperes (Musci: Calymperaceae) in Malaysia and adjacent regions. Bryologist 88:98-109.

Richards, P. W. 1984. The ecology of tropical forest bryo 